Meta

Journal des traducteurs

Translators' Journal

\title{
Translation for Reading Aloud
}

\section{Cay Dollerup}

Volume 48, numéro 1-2, mai 2003

Traduction pour les enfants

Translation for children

URI : https://id.erudit.org/iderudit/006959ar

DOI : https://doi.org/10.7202/006959ar

Aller au sommaire du numéro

\section{Éditeur(s)}

Les Presses de l'Université de Montréal

\section{ISSN}

0026-0452 (imprimé)

1492-1421 (numérique)

\section{Découvrir la revue}

\section{Citer cet article}

Dollerup, C. (2003). Translation for Reading Aloud. Meta, 48(1-2), 81-103. https://doi.org/10.7202/006959ar

\section{Résumé de l'article}

Cet article examine la traduction de la littérature pour enfants destinée à être lue à haute voix en prenant pour point de départ pragmatique (ou théorique) le « contrat narratif » entre l'enfant (le public) et le lecteur comme dans la tradition orale de jadis. Nous soutenons donc que, du moins à l'origine, la littérature lue à haute voix était la continuation de la tradition narrative dans la famille élargie, adaptée aux conditions et aux moeurs de la famille nucléaire. La famille nucléaire était une innovation du XIX ${ }^{\mathrm{e}}$ siècle lancée par les nouvelles classes moyennes, qui perpétuaient la tradition narrative par des contes tels que ceux des frères Grimm en Allemagne et de Hans Christian Andersen au Danemark. En référence à un questionnaire informel soumis à des traductologues de onze pays, nous concluons que la tradition de la lecture à haute voix pour les enfants se porte bien. Ceci nous amène à un modèle de situation de traduction pour la littérature lue à haute voix demandant des principes directeurs dans l'exploration des différences entre " les originaux " et « les traductions ». Après la présentation d'aspects tels que ceux de la structure, de la linguistique, du contenu et de l'intention, un aspect paratextuel et chronologique est aussi nécessaire en raison de la simultanéité des coéditions modernes et du besoin d'inclure des perspectives diachroniques. L'article discute des décideurs du processus de traduction tels que les éditeurs et autres et passe brièvement en revue des questions de tradition en matière de traduction avant de discuter les traductions des Contes de Grimm en anglais et en danois pour conclure qu'il existe deux écoles de " traducteurs respectables ", l'une ayant pour cible les contes à lire à haute voix et l'autre la lecture silencieuse, même si les traducteurs n'en sont pas conscients. La partie finale soulève les questions concernant la traduction de noms, de vers rimés et d'un texte extrêmement complexe, qui est discuté en profondeur. La conclusion est que la traduction destinée à être lue à haute voix est un art exigeant une grande compétence de la part des traducteurs. Elle devrait aussi retenir davantage l'attention des traductologues parce qu'elle remet en question des fondements du travail de traduction qu'on retrouve dans d'autres types de traductions.
Ce document est protégé par la loi sur le droit d'auteur. L’utilisation des services d’Érudit (y compris la reproduction) est assujettie à sa politique d'utilisation que vous pouvez consulter en ligne.

https://apropos.erudit.org/fr/usagers/politique-dutilisation/ 


\title{
Translation for Reading Aloud
}

\author{
CAY DOLLERUP \\ University of Copenhagen, Copenhagen, Denmark \\ cay@hum.ku.dk
}

\section{RÉSUMÉ}

Cet article examine la traduction de la littérature pour enfants destinée à être lue à haute voix en prenant pour point de départ pragmatique (ou théorique) le «contrat narratif» entre l'enfant (le public) et le lecteur comme dans la tradition orale de jadis. Nous soutenons donc que, du moins à l'origine, la littérature lue à haute voix était la continuation de la tradition narrative dans la famille élargie, adaptée aux conditions et aux mœurs de la famille nucléaire. La famille nucléaire était une innovation du XIX siècle lancée par les nouvelles classes moyennes, qui perpétuaient la tradition narrative par des contes tels que ceux des frères Grimm en Allemagne et de Hans Christian Andersen au Danemark. En référence à un questionnaire informel soumis à des traductologues de onze pays, nous concluons que la tradition de la lecture à haute voix pour les enfants se porte bien. Ceci nous amène à un modèle de situation de traduction pour la littérature lue à haute voix demandant des principes directeurs dans l'exploration des différences entre «les originaux» et «les traductions». Après la présentation d'aspects tels que ceux de la structure, de la linguistique, du contenu et de l'intention, un aspect paratextuel et chronologique est aussi nécessaire en raison de la simultanéité des coéditions modernes et du besoin d'inclure des perspectives diachroniques. L'article discute des décideurs du processus de traduction tels que les éditeurs et autres et passe brièvement en revue des questions de tradition en matière de traduction avant de discuter les traductions des Contes de Grimm en anglais et en danois pour conclure qu'il existe deux écoles de «traducteurs respectables », l'une ayant pour cible les contes à lire à haute voix et l'autre la lecture silencieuse, même si les traducteurs n'en sont pas conscients. La partie finale soulève les questions concernant la traduction de noms, de vers rimés et d'un texte extrêmement complexe, qui est discuté en profondeur. La conclusion est que la traduction destinée à être lue à haute voix est un art exigeant une grande compétence de la part des traducteurs. Elle devrait aussi retenir davantage l'attention des traductologues parce qu'elle remet en question des fondements du travail de traduction qu'on retrouve dans d'autres types de traductions.

\section{ABSTRACT}

The article takes a look at the translation of children's literature intended for reading aloud. The pragmatic (or theoretical) point of departure is a 'narrative contract' between the child (audience) and the reader as in the oral tradition of yesteryear. It is therefore argued that, at least initially, children's literature for reading aloud was a continuation of the narrative tradition in the extended family adapted to the conditions and mores of the nuclear family. The nuclear family was a 19th century innovation promoted by the new middle classes, and they best carried on the narrative tradition by means of stories such as those of the brothers Grimm in Germany and Hans Christian Andersen in Denmark. Referring to an informal questionnaire among Translation Studies scholars covering eleven countries, it is concluded that the tradition of reading aloud for children is alive and well. This leads to a model for the translational situation for read-aloud literature that calls for guiding principles in the exploration of differences between 'originals' and 'translations.' Having introduced such layers, viz. the structural, the linguistic, the content and intentional ones, a paratextual and chronological layer are also called for, because of 
the ubiquity of modern co-prints and the need to introduce diachronic perspectives. The article discusses decision-makers in the process of translation, such as publishers and the like, and also briefly views questions of translational traditions before it discusses translations of the Grimm Tales into English and Danish, to conclude that there are two different schools of 'respectable translators,' one targeting stories for reading aloud and another for silent reading, even though the translators may not be aware of this. The final part takes up questions concerning the translation of names, rhymes, and a highly complex text which is discussed in depth. The conclusion is that translation for reading aloud is an art requiring great competence of translators. It also ought to attract more attention from Translation Studies scholars because it questions fundamentals in translation work that are also found in other types of translation.

Readers should read aloud the passages cited in order to appreciate the commentary!

\section{MOTS-CLÉS/KEYWORDS}

Danish, English, fairytales, history, reading aloud

\section{Introductory comments}

In this article, I shall address the question of the translation of children's literature, notably the type that is read aloud.

It is paradoxical and yet inevitable that children's literature should be studied by adults. Similarly, it is mostly adults who author, illustrate, publish, distribute, review and purchase books for children. There will thus, inevitably, be a built-in adult bias in any discussion.

This also goes for the history of children's literature. When, as in the present article, reading aloud is in focus, there is little doubt that the crucial point is the interaction between a narrative (a 'text'), an (adult) person reading aloud, and a child audience. We might illustrate this as follows:

\section{Illustration 1}

Person reading aloud

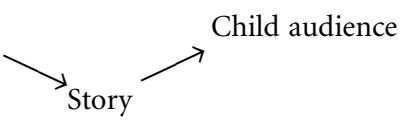

This figure illustrates that the presence of a child may prompt an adult (or older child) to read aloud from a book. It is less obvious how we should view the relationship between the child and the person reading aloud. It could also be argued that the figure should start with the child asking to have a story read out, bringing a book, and prompting an adult to read aloud. However, in order not to complicate matters unnecessarily, it is wisest to stop at asserting that an interaction takes place between the parties involved (illustration 2):

\section{Illustration 2}

Person reading aloud

Using the concept of 'a narrative contract,' a situation comprising a narrator and an audience willing to hear a story (Dollerup 1999: 28-29), we get a much more 
complex picture of sending and feedback in narration (including reading aloud) which, in a simplified form, looks as follows:

\section{Illustration 3}

\begin{tabular}{|l|}
\hline Narrator \\
Narrative \\
Narrator's response to feedback \\
\hline
\end{tabular}

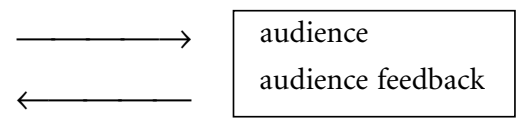

If this 'narrative contract' is satisfactory to all parties, there will be requests for new ones and if not, there will be no more 'narrative contracts' between the narrator and the audience in question. (For further discussion, see Dollerup 1999. Index).

The point is to call attention to the fact that oral literature always has drawn (and in some countries still draws) listeners - quite often large audiences. Oral epics, romances, ballads, folktales and the like have entertained listeners from different social strata and age groups, including children. Focusing mostly on prose narratives, specifically folktales, it is obvious that there may be 'messages' for different addressees in much folkloristic material. Tall tales have appealed to adult male audiences, whereas others, using the paraphernalia of wonder and magic, have had different messages for different age groups. This is not always obvious, for, unfortunately, virtually all so-called 'authentic' European folktales available to the public in printed books have been edited - this includes Bogatyrev's Russian tales (that served Vladimir Propp for his morphology of narratives) and the Grimm Tales. ${ }^{1}$

Nevertheless, we may, in order to show the differences in addressee orientation, deal with one well-known fairytale. The Frenchman Charles Perrault included 'Little Red Riding Hood' in his Contes de fé (1695). In this tale, Little Red Riding Hood who strays from the direct path to her grandmother's house, is devoured by the wolf. Full stop. Therefore the story can end with a moralistic warning about the importance of doing what you are told and not being seduced by 'wolves' (men). It is somewhat difficult to see this as a story that any parent, nanny, or educator would read to a child under ten. The Grimm version, 'Rotkäppchen' (1812), has a happy ending in that a hunter shoots the wolf. To adults, there is still no doubt that, at one level, this is a story of seduction successfully averted, since both Little Red Riding Hood and her grandmother survive their stint in the wolf's stomach; but although children are admonished to follow parental advice, the happy ending also implies that most adults are decent people who will save children in trouble. This is a story appealing to a wider audience.

\section{Reading aloud as a continuation of the oral tradition}

In other words, children's literature meant for reading aloud has a (pre)history different from that of children's literature meant for silent reading, for reading on your own.

I see the precursors of the reading aloud stories in the oral narrative tradition. This tradition seems to inform Charles Perrault's collection (1695). In spirit, if not in fact, it also informs the tales of the brothers Grimm which appeared in 1812 and 1815. ${ }^{2}$ This was also one of the first books to explicitly state, on the very title page, 
that it was meant for children: Kinder- u. Hausmärchen ('child and household tales'). The collection was dedicated to a newborn boy and his mother, and in their preface the two brothers Grimm stressed that these stories originally "belonged to children" and had "been torn out of their hands." The stories were read aloud to children in German families as witnessed in letters to the brothers. However, some of their adult audiences objected to cruelty in some tales. The collection was not clearly targeted towards children until 1823 when Edgar Taylor and David Jardine translated a selection into English which was published with pictures. This, in turn, inspired Wilhelm Grimm to compile an illustrated selection comprising only 50 tales in German. Most of these were what we would loosely term 'fairytales.' In his preface to this Small Edition (Kleine Ausgabe), Wilhelm Grimm stated that "the selection ... has in mind those who do not think all the tales in the Complete Edition are suitable for children." (My translation). This first selection of stories for children appeared in 1825, and a new edition in 1833 marked the beginning of the rise to popularity of the Tales in Europe.

No Danish translator was ever in doubt that the Grimm tales were for children. But, at the same time, the Grimm tales enjoyed enormous prestige in Denmark. Every educated person spoke German, since one third of the country was Germanspeaking (Slesvig-Holsten), and the ties with Germany were close. The first volume of the Tales was soon for sale in Copenhagen. ${ }^{3}$ Six Grimm tales were translated in 1816 by the most prominent Danish Romantic poet Adam Oehlenschläger for a volume of stories from many countries. A translation of the first volume of the German Tales appeared in 1821 (1823). In 1816 Rasmus Nyerup, the head of the University Library in Copenhagen that housed the manuscripts of the Icelandic Edda, which the brothers Grimm considered of prime importance to Germanic studies and even procured copies of, published a book with (semi)folkloristic material from Denmark and Norway. On the front page, this book featured a printed dedication to the thirty-year old Wilhelm Grimm who was termed one of the foremost German literary historians. ${ }^{4}$ The same year, Professor Nyerup and the impact of the Grimm tales prompted a young man, Matthias Thiele, to collect Danish local legends for four summers from the oral tradition of the common folk - the first genuine large-scale folklore collection in the world. Furthermore, the brothers Grimm knew Danish, and therefore understood the implications of the findings of the Danish linguist Rasmus Rask concerning 'Thracian' (now 'Indo-European'). These were published in a book written in Danish (1818) on the origins of Icelandic. Wilhelm Grimm put Rask's discoveries to use in a forty-page introduction to the second edition of the Tales that appeared in 1819. In this introduction, Wilhelm Grimm argued that the German stories were part of ancient Pan-Germanic mythology that was best preserved in Norse myth and which was therefore extensively cited. This preface was translated into Danish, and even though it was dropped in subsequent German editions, it was printed in the prominent Danish collection until 1853. The enormous prestige tales and folklore thus enjoyed in Denmark serves to explain why Hans Christian Andersen was inspired to write fairytales. So, soon the tales of Andersen and the brothers Grimm became well known internationally by means of translation. ${ }^{5}$ 


\section{Read-aloud children's literature in a bourgeois context}

My argument is that at least from 1825 there was a body of children's literature in Europe that was explicitly intended for being read aloud to children. ${ }^{6}$ The large German Grimm edition may have been used for silent reading, and, in Denmark, there were already translations by 1825 meant for silent reading. The number of such editions rose thanks to advances in literacy brought about by reforms in the educational systems in the course of the following decades.

The increasing popularity in read-aloud literature for children - best exemplified in the Andersen and Grimm tales - cannot be attributed to the elitist 'salon culture' as Anz and others would naively have it (2000) but must be seen against a larger canvas stretching over the whole of the 19th century.

One contributing factor was the increased urbanisation and industrialisation. This led to the uprooting of the old narrative communities in the countryside and resulted in fewer opportunities for oral narration.

Another important factor was that the middle classes, which had existed since the Middle Ages, grew in size. They became a highly visible, increasingly educated bourgeoisie that took an active interest in the upbringing of its children. The family patterns of the middle classes led to the gradual replacement of the extended family by the nuclear family. In the extended family, there would have been good chances of having an accomplished narrator around, but these dwindled with the smaller-sized nuclear family. Fairytales and reading them aloud were an excellent replacement. They represented a fine opportunity for establishing 'narrative contracts' in the intimate sphere of family life, notably between grandparents, mothers, and children. With the emphasis on a "happy ending" (typically marriage and social advancement) as a reward for decent behaviour, good deeds, and resourcefulness, they also promoted norms dear to the middle-class way of life.

These are the social reasons underpinning my belief that the oral tradition was accepted and adapted so as to become the strongest precursor for children's literature to be read aloud in Europe and North America in the 19th century.

It is futile to go into a long discussion of what may or may not have been the case in various countries without tangible evidence that, at present, is not available. As mentioned, tales were read aloud to children in Germany. In Denmark, the general perception ever since Grimm stories were first translated and inspired the Andersen stories, fairy tales were definitely looked upon as the stuff for reading aloud (and sometimes, to be true, also material for silent reading).

\section{The present-day scene}

Thanks to information provided by colleagues and graduate students representing eleven different nationalities from Europe and Asia, we get a rough picture of the tradition of reading aloud at the beginning of the 21 st century (cf. appendix).

In interpreting the appendix, we must keep in mind that we are dealing exclusively with academics who (as noted by several participants) do not represent a 'cross-section of society. The appendix merely shows that the tradition is found in many countries. Many participants emphasise that the situation has changed during their lifetime and that television seems to have an impact. There are also variations in 
the answers given within the same country, so in all likelihood we are dealing with a high number of variables - including market differences, differences in terms of national literature (there are countries that have little home-grown children's literature), and so on.

Nevertheless, the appendix illustrates that reading aloud is fairly common in many societies in the world, that it is a pastime directed towards children from a very early age (several answered 'from birth') until, it seems, the children themselves can read. It also illustrates that it is primarily connected with the nuclear family. There seem to be fuzzy dividing lines between authentic narration, retelling and reading aloud in so far as one participant was told oral stories, while others referred to the interactive aspects (elucidating words etc.) in the process of reading aloud.

It also stresses, if only indirectly, that there are other types of literature for children - even among those texts listed for reading aloud, we find not only the international fairytales but also poetry and traditional national stories as well as modern national children's fiction and international co-prints. ${ }^{7}$

Obviously national stories are outside the realm of translation altogether. In all likelihood, poetry would also mostly be national (e.g., nonsense verse, nursery rhymes), but, as we shall see, it sometimes crops up in translations of books for reading aloud.

\section{The implications for translators}

The translators' role in the mediation of children's literature is logically limited to foreign literature. For all the talk about e.g., the translators' power, visibility and whatnot, it is limited in other ways as well. It is limited by market forces, by the potential intervention of in-house editors or publishers, and, last but not least, by the format of the book for which the translation is made. These are some of the points that will be explored on the following pages.

\section{Marketing systems and translators as retellers}

In exceptional cases, and in countries where translators are also publishers, they may be able to promote or publish specific children's books (e.g., Denmark and Slovenia. Dollerup and Orel-Kos 2001: 96).

However, in most cases, it is the powers that be in publishing houses that acquire books. They may do so at international book fairs (especially at the Bologna book fair in Italy (in spring)), through ads exchanged between publishers, from information obtained from 'scouts,' and so on. This is not a haphazard process but one characterised by careful selection (Dollerup and Orel-Kos 2001: 95; Dollerup 1999: 247-250). The publishers then turn to hired translators or salaried free-lancers who must target the text towards a child audience in the target culture, or rather, towards an audience of purchasers who appreciate (and assess) the book's potential for being read aloud (e.g., parents and librarians).

At this stage, then, there is an element of re-telling in translation. If we elaborate on the model proposed at the beginning of this article, we must first assume that the book has met with success in the source culture and has been involved in successful 'narrative contracts.' ${ }^{\prime}$ This interplay can be illustrated as follows: 


\section{Illustration 4}

\section{SOURCE LANGUAGE:}

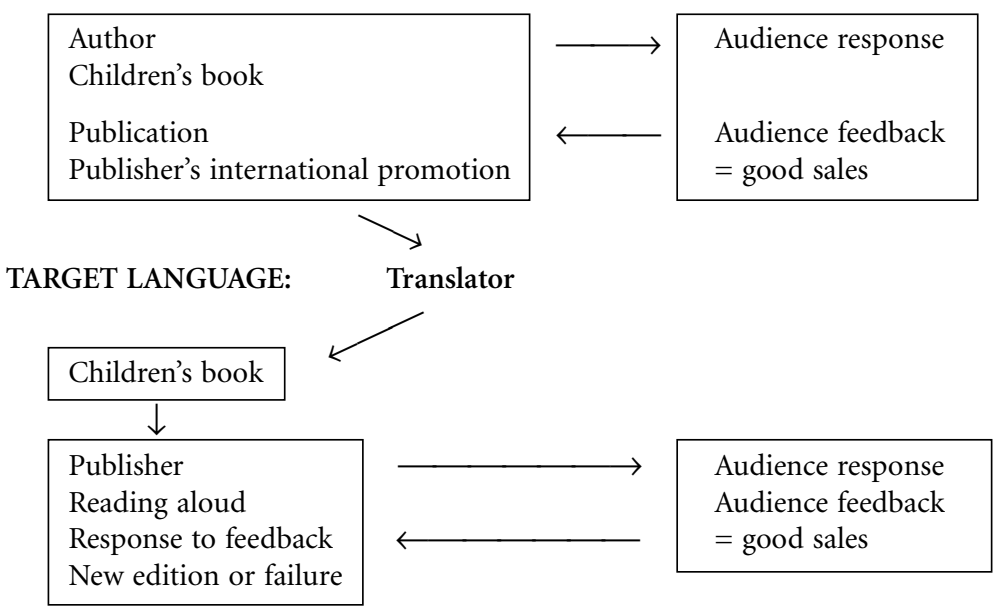

\section{The layers in originals and translations}

In order to discuss the translation of literature for reading aloud, it is necessary to have some guidelines. In Tales and Translation, I set up a model for discussing originals and translations in a way which, as one reviewer pointed out, offers "nonjudgmental criteria for [the] assessment of the 'adequacy' of a translation which avoid such conflicted notions as 'fidelity' to the source text, or censorship operating in the receptor culture." (Seago 2001: 120).

\section{The textual layers}

The model is simple and operates with four layers in texts which, despite some overlapping, allow for cogent discussions:

- the structural (the textual order of elements, passages, and episodes),

- the linguistic (including words, word order, phrases, repetitions of words, sounds, assonance, euphony, and 'style'),

- the content ('facts', and points and elements in the structural and linguistic layers which can serve for interpretation), and

- the intentional layers.

The content layer, relating to points or segments in texts, generally allows for interpretation in the sense of a text-internal, consistent meta-understanding of specific texts; the intentional layer will usually allow for an external meta-understanding of the text as related to human experience (ranging from morals to universal transitions in life). (Dollerup 1999: 47).

\section{The paratextual layer}

To these four layers we also have to add the paratextual layer, which is becoming clearer than it was a mere four years ago:

In nations using minor languages, the majority of translated children's books are also picture books. The interplay between pictures and text has been discussed from 
several angles (e.g., Oittinen 1993: 115-132; Dollerup 1999: 255-276; Oittinen: 2000; Oittinen: 2001; Houlind 2001). We may offer a tentative outline of the processes.

First it must be stressed that there are problematic cases: practising translators have reported to me that sometimes they are not given the pictures at all. This may lead to blatant discrepancies between picture and text in the target texts (private communication from Annette Lindegaard and Susanne Aagaard; see also Oittinen 1993: 131). Although it is clear that this is the publisher's rather than the translator's fault, you can rest assured that no reader is aware of this and therefore would consider these 'translation errors.'

Disregarding such lamentable cases, translators tackle the picture-text relationship as follows:

(a) The translator uses the picture(s) for emphasising some features (Oittinen: 1993: e.g., 124-127).

(b) The translator may deviate from the text of the 'original' in order to make picture and text correspond (Dollerup 1999: 262).

(b) The translator may deviate from what is shown in the pictures (Dollerup and Orel-Kos 2002: 92-93; Houlind 2001: 131-133).

(c) The picture may - for practical reasons - lead to shortening in the text (Dollerup 1999: 262; Dollerup and Orel-Kos 2001: 92)

(d) The source texts may be provided with other pictures which will then lead to different (new) translations - a type to be discussed below. This has been documented extensively in Dollerup 1999 (e.g., 107, 109, 111-112, 119-120, 124-125).

Co-prints deriving from the same 'original' may differ so much that the unsuspecting reader will not be aware that they derive from the same 'original' (Dollerup 1999: 265-266).

To this we may add other combinations unearthed in Tales and Translation, such as numerous 'relay translations' that lead to different illustrations and texts in different countries and to different realisations in the target language.

\section{The chronological axis}

Finally, in the light of the above discussion, it will be clear that there is also a chronological axis. From a fairly high number of cases that have come to my attention over the years, it seems that at some stage or other, many target cultures 'feel a (cultural) need' to have complete translations of many classics. In cases where these classics have become children's literature, this may be different.

Some of these may never have made it to other languages. I doubt that there are any continental versions of the full 'original' text of Daniel Defoe's Robinson Crusoe and Jonathan Swift's Gulliver's Travels that would be met with approval by philologically-minded translators. Be it noted that these books have had an enormous impact on Western culture. But this is definitely not because of 'faithful translation' at any of the layers discussed above.

Both the brothers Grimm and Hans Christian Andersen proclaimed on the title page of their first collections that the tales were for children. However, the brothers Grimm also had a scholarly audience in mind. They solved this dichotomy in 1825 by publishing a selection of 50 stories targeted specifically towards children; it comprises all the most popular stories (Dollerup 1999: 56-59). Hans Christian Andersen appears originally to have started to write fairytales (advertised in May 1835) because he was 
hard pressed for money despite his reasonable success as an author in Denmark. Later he - rightly - concluded that the content could also stand up to adult inspection.

The history of the translation of Andersen's fairytales into German ('Gesammelte Werke') is somewhat sketchy, and the more than 10 editions seem to be based on a relatively limited number of translations, and since an investigation of their suitability for reading aloud is beyond my ken, I must leave it at this.

As far as translations of the Grimm's tales into English are concerned, Martin Sutton (1996) discusses the first Complete Collection (1884). It was made by Margaret Hunt, who accepted Grimm's dubious claim that the stories were from the oral tradition. Accordingly, she even translated the notes of the last German edition which Wilhelm Grimm saw to the press, the 'Ausgabe der letzten Hand' (1857), since her translation was obviously directed towards scholars. It seems as though both she and subsequent reviser(s) have stuck to this idea. Overall, Sutton characterises her translations as "faithful" (262-263), which, in our context and to use Sutton's words, "undermines their readability" (274).

Martin Sutton discusses the pseudo-dialectal 'The Juniper Tree' in detail. In English, the opening lines run:

"It is now long ago, quite two thousand years, since there was a rich man who had a beautiful and pious wife, and they loved each other dearly. They had, however, no children, though they wished for them very much, and the woman prayed for them day and night, but still they had none" (Sutton 1996: 268).

Sutton reports that subsequently Hunt's translation was reissued by Bohn's Standard Library and George Bell (1885, 1892, and 1910), in a revised form in 1944 (US), and reissued in the UK in 1948, 1959, and 1975. This last edition is in my possession, and I can therefore report that there are no changes in the above excerpt. The revisions must have been fairly superficial.

Sutton also discusses Lucy Crane's translation of the same story (1882). It ran:

"A long time ago, perhaps as much as two thousand years, there was a rich man, and he had a beautiful and pious wife, and they loved each other very much, and they had no children, though they wished greatly for some, and the wife prayed for one day and night." (Cited in Sutton 1996: 268).

This is markedly easier to read aloud - which any reader can try to do with the excerpts. Small wonder, then, that this edition has been reprinted more frequently. Sutton lists editions from 1886, 1893, 1894, 1926, etc. (1996: 303-204). Personally, I have a reprint in the Wordsworth Classics series from 1993. It is slightly surprising that, just as in Margaret Hunt's translation, nobody seems to have changed the punctuation in the intervening period.

This at least was changed in Jack Zipes’ American translation (1987 hc, 1992 pb):

"All this took place a long time ago, most likely two thousand years ago. There was a rich man who had a beautiful and pious wife, and they loved each other very much. Though they did not have any children, they longed to have some. Day and night the wife prayed for a child, but still none came, and everything remained the same." (Zipes 1992: 171).

Once again, we deal with a translation that is easy to read out. It is markedly longer than the others, which testifies to a sort of compromise between fluency and 'fidelity' (shown in particular in the "day and night"). 
The above examples, however, suffer from a weakness in that they are not the type of translations that are made exclusively with sales in mind but are targeted towards an educated public who want the 'real Grimm.' They are thus relatively 'classy' and have been made by credited translators. This means that, accepting that there is considerable latitude in translation work, we must consider them all adequate at all layers.

However, the most popular English edition seems to be Household Stories by the Brothers Grimm which was published by Addey \& Co. in London in 1853. Sutton discusses the translations (162-184) and finds the quality "fluctuating," possibly due to the fact that there was a team of translators. This edition has appeared in the US and even in Australia. Reprints have been registered with a variety of publishers in 1857, c 1890, 1904, 1906 (rpts), c 1909, 1920, 1941, 1981, 1981, 1984, 1985, 1986, 1987, 1989 (Sutton: 183) and 1990 (colophon of my copy). Sutton considers the translations uneven, inconsistent, and unreliable, and is surprised that, in view of the fact that it was followed by more "readable" translations, it has "had an amazingly long life" (182-183).

'The almond-tree' opens:

"Long, long ago, perhaps two thousand years, there was a rich man who had a beautiful and pious wife; and they were very fond of one another, but had no children. Still they wished for some very much, and the wife prayed for them day and night; still they had none."

It is noted at once that this is eminently suited for reading aloud. The punctuation clearly signals pauses to the person reading aloud. Except for the content difference that 'The juniper tree' of the original is rendered as "The almond-tree,' we are hard put to argue that this translation differs from the original in other respects except at the linguistic layer and then only so as to ease narration through the use of repetitions ("long ... long," "still ... still").

The above excerpts and the discussion illustrate that translation critics with a philological background and approach define 'readability' in radically different terms than the translators - even the anonymous ones who target their product for mothers who read stories aloud for their children. ${ }^{9}$

\section{Constraints on translators}

As shown in illustration 4, the prime obligation for a translator of material for reading aloud is that $\mathrm{s} / \mathrm{he}$ must do her/his best to ensure that the text will make for successful 'narrative contracts' in the target culture. Of course, this requires that the content of the translation be captivating and that - as just noted - the story reads fluently so as to be easy to tackle for people who read it aloud. A few translators of children's literature have reported that - as part of the process of translation - they read texts which they consider typical 'read-aloud literature' (Dollerup and Orel-Kos 2001: 96; Oittinen 2001: 121; private information from Susanne Vebel). We shall return to the implications of this constraint below.

\section{Publishers and editors}

In the first place, it must be kept in mind that, more often than not, the translator does not have the first nor the final say on how the text is going to be rendered in the 
target language. When, for instance, the English philologist Glyn Jones (1993) wails about a publisher's manhandling of his translation of Hans Christian Andersen ("What have they done to Andersen? A cautionary tale." My translation), he neglects to mention the publisher's legitimate right to make money from books, and therefore that purgation of religious interpolations in a 'philologically faithful' translation makes sense. The religious elements in Grimm and Andersen are not relevant to and might even diminish the enjoyment of modern readers. And, since we do know that both Wilhelm Grimm and Hans Christian Andersen savoured popularity, it would be 'disloyal' to the 'senders' to retain the outmoded religious strands.

Purgation, which affects both the linguistic and the content layers, has been used all through the history of translation of children's literature, notably of tales and adult literature that has become children's literature. But it is difficult to tell whether such 'purgation' has been undertaken by translators, editors, or publishers (Dollerup 1999. Index). ${ }^{10}$ Even so, it is doubtful that the concepts of 'censorship' or 're-writing' are useful. They overestimate the 'power' of the translator: 'cultural incompatibility' seems to be a more felicitous term for the adjustment to new target cultures and target epochs in which some of the morals and beliefs in old stories would be incomprehensible and perhaps even considered reprehensible. Translators are not alone in exerting control over 'cultural incompatibility.' Editors and - most of all - publishing houses are more likely to be aware of it (see Dollerup and Orel-Kos 2001: 95).

\section{Translational traditions}

Stories that have been translated often may present problems that have to do with translational tradition in that older 'readers-aloud' may be familiar with another phrasing. In the first German editions of 'Hansel and Gretel' in the Grimm Tales $(1812,1819,1837$, and 1840), it was the children's own mother who came up with the idea of abandoning them in the woods. All German editions from 1848 onwards changed the woman into a "stepmother." Nevertheless, respectable Danish translations continued to insist that the woman was the children's own mother as late as 1972. This can only be ascribed to a strong tradition in the rendition of the tale, since pirating of previous translation is virtually unknown in Denmark. The 'mother' 'stepmother' as such will not jar the reading, but there is a considerable difference both at the content layer as well as at the intentional layer in that the story is most definitely turned into a tale of active parental rejection of their own offspring. The introduction of the mother would probably shock a modern child.

In the same vein, it is obvious that translators will respond differently to the formulaic opening "once upon a time" depending on the traditions of the target culture: "Es war einmal ..." in German, "Der var engang ..." (= There was once) in Danish. If such traditional - one might say 'culturally embedded' - patterns are not followed (at the structural and linguistic layer), the translator may face an uphill struggle to become successful.

\section{Complete Editions of Grimm in Denmark}

It will be recalled that the second Danish translation of the Grimm stories was an uncritical rendition of the first volume of their Tales (1821/1823). Ascribed to an old nobleman, Chamberlain Johan Lindencrone, some of the stories (but not all) in this 
collection must have been revised or retranslated by his daughter, since most source texts are found in the second German Edition (1819) and the elder Chamberlain died in 1817. Circumstantial evidence (the 'Dedication to the reader' in particular) indicates that Lindencrone translated the stories for the purpose of reading them aloud to his grandchildren. This first translation - and we shall here focus on 'Hansel and Gretel' - is easy to read aloud in Danish, even today:

"Foran en stor Skov boede en fattig Brændehugger, som intet havde at bide eller at brænde og neppe det daglige Brød for sin Kone og deres to Børn, Hans og Gretelil.”

("A poor woodcutter who had nothing to eat and nothing to heat and hardly a daily meal for his wife and their two children, Hans and little Gretel lived on the edge of a large wood." My translation - the comments apply to the Danish version).

In a form that was merely changed in accordance with changes in language usage due to orthographical reforms, this translation was last printed in 1909. The longevity was to a large extent due to the 'snob value' and one must assume - indeed hope - that careful parents checked on the contents of stories before they read them out loud. ${ }^{11}$

The first Complete Edition to include all tales from both German volumes was marketed in Denmark in 1894:

"Ved udkanten af en stor Skov boede der en fattig Brændehugger med sin Kone og sine to Børn; den lille Dreng hed Hansemand, og den lille pige hed Gretelil."

("A poor woodcutter lived on the edge of a large wood with his wife and his two children. The little boy was called darling Hans and the little girl was called little Gretel").

Despite the idiomatic rendition and high readability - small surprise as the translator (Jacob Daugaard) was also an actor - it was superseded within eleven years by another Complete Grimm by the author Carl Ewald (1905). His opening of the story ran:

"Ved udkanten af en stor Skov boede en fattig Brændehugger med sin Kone og sine to Børn. Drengen hed Hans og pigen hed Grete."

("A poor woodcutter lived on the edge of a large wood with his wife and his two children. The boy was called Hans and the girl was called Grete.").

This is also a highly readable translation. On the linguistic side, the sentences (with full-stops) are shorter. The telling difference is that, whereas Daugaard was more idiomatic in Danish, he also rendered the diminutives ("Hansel" and "Grethel") of the German stories into Danish. This fidelity at the linguistic layer accumulates (in Danish) to an overall sentimentality that was not acceptable to the Danish middleclass public that would buy the Complete Collection.

These three collections co-existed with yet other translations of 'Hansel and Gretel' of which I have tracked down nearly one hundred published between 1816 and 1986. In reasonably adequate translations, there is a tradition in Denmark dictating that the story of 'Hansel and Gretel' should start head-on the way it does in the above excerpts. Since there were no successful collections of fairytales in Denmark when Lindencrone and his daughter's translation was published, there was no formulaic opening either. The formulaic opening was first introduced in 1843 by Christian Molbech, a professor of Danish with a good knowledge of folktales from numerous countries: 
"Der var engang en fattig Brændehugger, som boede nær ved en stor Skov..."

- and since then, up to the present day, the two different openings have competed.

However, Carl Ewald's translations were reprinted many times. After the copyright expired, publishers issued slightly linguistically updated Carl Ewald texts in publications which ranged from single-tale books to a volume comprising the Complete Tales which was a success and reprinted five or six times after its first appearance in 1975.

In 1993, a Danish scholar argued that Carl Ewald's translation was inaccurate. He cited the suppression of, for instance, religious features and a passage in which the German 'Rabe' which was flying was rendered as a 'hare,' rather than "correctly" as a 'raven' (as if one can demand realism in a tale). Disregarding - or perhaps even unaware of the tortuous textual history of the German originals (Dollerup 1999: 3051; with reference to Rölleke) - he argued that an updated translation should be made both for the general public and for scholarship, since he always had to consult the German 'original' rather than Carl Ewald's Danish translation. The Grimm Tales being part of the Danish cultural heritage, a Danish author, Villy Sørensen, was commissioned to do a new translation. This was issued by the most prestigious publishing house in Denmark on the occasion of its 225th anniversary. This translation was favourably reviewed because it was new (see Dollerup 1999: 343 for quotations).

The first line of 'Hansel and Grete' ran:

"I udkanten af en stor skov boede en fattig skovhugger med sin kone og to børn, en dreng, der hed Hans og en pige, der hed Grete." ("A poor woodcutter lived on the edge of large wood with his wife and two children, a boy called Hans and a girl named Grete").

One is hard put to see what precise improvement has been made in this sentence. The striking feature is that Villy Sørensen agrees with virtually all translators from 1900 onwards that the story should not render the diminutives: in other words, just like all other translations, this 'faithful' translation elides a feature which I have termed 'culturally incompatible.' So even this translator fails to render something at the linguistic layer. In the last authorised German version from 1857, ${ }^{12}$ 'Hansel and Gretel' has six religious comments which have been toned down a bit by Danish translators, and all members of the Danish 'corps des traducteurs' - including Villy Sørensen - fail (or refuse) to translate Hansel's comment when the children come to the pancake house: "eine gesegnete Mahlzeit" ("a hallowed/sacred meal"). In this case, the Danish translators are not only tampering with an innocent piece of linguisticcum-content layer. They also turn an 'original' which, at one level, is concerned with life at the brink of starvation, into a modern story advocating Spartan Protestant mores that children should not have too many sweets and under no circumstances be given the chance to have their fill.

In 'Snow-White' we meet with much the same thing: the invocations to God are weakened into what are, in Danish, mild expressions of surprise. In the German opening Snow-White is, it seems, conceived because, looking towards Heaven while snow is falling, her mother wishes to have a child. In Danish the queen merely looks at the snow falling; and the 'gottlose' (= godless) stepmother who takes over in the German edition is toothless in Danish ('ryggesløs'). This word is more indicative of a lack of moral rectitude in the wicked stepmother than of any lack of faith in God. 
It is indeed hard to say whether the shift in emphasis is due to a lack of religious insight or adaptation to a modern Danish audience.

In other places the new edition certainly met the standards of fidelity required. Thus the opening lines of the very first tale, 'The frog king' run:

"I gamle dage da det endnu hjalp at ønske, levede der en konge der havde mange smukke døtre, men den yngste var så smuk at selv solen, der dog havde set så meget, måtte undre sig hver gang den skinnede hende i ansigtet." ("In the good old days when wishes might still be fulfilled, there was a king who had many beautiful daughters, but the youngest was so beautiful that the sun itself, which had seen so many things, was struck with wonder every time it shone into her face." My translation - comments are on the Danish text).

Whatever one's feelings about having the sun shining right in one's face, Villy Sørensen has here rendered all the linguistic and content elements of the German original. In a linguistically updated version, Carl Ewald's translation has it as follows:

"I gamle dage, dengang man kunne få sine ønsker opfyldt, levede der en konge, som havde en datter, der var så dejlig, at selv solen, der dog har set så meget kønt, undredes hver gang den skinnede på hende." ("In the good old days when one's wishes might still be fulfilled, there was a king who had a daughter so lovely that even the sun which has seen so many delightful things, was struck with wonder every time it shone on her").

By means of a major difference at the content level, Carl Ewald has eliminated the king's other daughters, which, indeed, serves as a good indicator of the degree to which translation may affect family life.

On the other hand, there is no denying that Villy Sørensen's so-called 'faithful' translation is no good for reading aloud. The book was duly acquired by the more than 270 municipal libraries in Denmark. All parents that I have spoken with had one look at the book and decided not to buy it. It was put out for the annual discount sale within two years of its publication. A selection of Grimm tales published in 2001 by another publisher (Sesam), with updated illustrations by Cato Thau-Jensen, again reverted to the Carl Ewald translations. This has nothing to do with copyright but with readability.

In translation, the Grimm tales (and in all likelihood Andersen's as well) thus call for sensitivity to reading aloud above all else. In the examples discussed, it even seems that the translators who paid attention to this feature were not only more successful in the target cultures, but were also able to carry across more of the intentionality of the tales.

\section{Modern translations}

\section{Names}

Names in children's books are frequently changed - sometimes one fails to see why. Thus I do not see why Maggie Glen's Ruby (UK 1990?) had to be translated into Sally (Danish 1999), but perhaps it has to do with readability in some subtle way. In other cases, but for silent reading, translators of children's books in Denmark traditionally render unusual English and American names into English and American names that are more well known to Danes and also shorten them. 


\section{Rhymes}

Many participants in the small-scale study (cf. appendix) mention that poetry is read to children, and one does not have to look far to realise that small bits of poems are found in children's books. Some of these books are translated.

Jez Alborough's Where's My Teddy? (US 1992) is a story in rhyme about a boy who goes in search of his teddy bear which is lost in a wood. ${ }^{13}$ The two first full-page pictures frame the playful story:

"Eddie's off to find his teddy.

Eddie's teddy's name is Freddie.

He lost him in the woods somewhere.

It's dark and horrible in there.

'Help!' said Eddie. 'I'm scared already!

I want my bed! I want my teddy!”

This book made it as an international co-print to France where it appeared in 2000, translated by Isabel Finkenstaedt.

Fred, le nounours d'Eddie, a disparu.

Eddie part à sa recherche.

Fred est perdu quelque part dans le bois.

Plus Eddie s'avance, plus il fait sombre.

'Au secours! Crie Eddie. J'ai peur!

Je veux mon lit! Je veux mon nounours!”

One gets the impression that the translator may not have noticed the rhyme of the original. In any event, the linguistic layer is not the same in French as in English. There is a difference at the structural layer, so that Fred plays a larger role in the beginning. Eddie is more active, and there is a causal connection between his advance into the wood and its sinister character. So there are structural, linguistic, and content differences between the American original and the French translation. It is, of course, hard to know what we are dealing with here. The translator may have been given a free hand, have been ignorant of the American text, have chosen to adapt it to a French audience, etc.

Except for the problematic 'le nounours' (and, perhaps, line three), the translation reads smoothly, and the overall intentionality (once our teddy bear has been recovered, Eddie also forgets the surprises in the wood) is also preserved.

'Hansel and Gretel' also contains some rhymes. house:

The first one is uttered by the old witch when the children start eating the pancake

"Knuper, knuper, kneischen,

wer knupert an meinem Häuschen?”

and the children answer:

"Der Wind, der Wind,

das himmlische Kind.” (Rölleke 1987. Vol. 1:104)

Of course the phrasing "the heavenly child" is part of the religious strand in the story (as it stands).

In the most long-lived translation in English (1853) these verses are rendered “Tip-tap, tip-tap, who raps at my door?" - "The wind, the wind, the heavenly child." 
It is a rendition which is different at all layers and does not make sense, since (a) the children are not touching the door and (b) the religious strand is downplayed in other places.

Crane's translation (1882) goes:

"Nibble, nibble, like a mouse,

Who is nibbling at my house?"-

"Never mind,

it is the wind."

Hunt's translation (1884) sounds:

"Nibble, nibble, gnaw.

Who is nibbling at my little house?" -

"The wind, the wind,

The heaven-born wind."

It is fair to assume that Hunt must have known Crane's translation (“... nibbling at my house?"). Overall, both seem to have been unsuccessful at the linguistic layer: the rhymes of the second stanza are not good even as autonomous texts. Hunt seems to render the content most adequately, but both translations have weakened the religious (content) strand by rendering the "gesegnete Mahlzeit" as, respectively, "a glorious meal" and "a good meal."

Jack Zipes renders the verses:

"Nibble, nibble, I hear a mouse.

Who is that nibbling at my house?" -

"The wind, the wind; it's very mild,

blowing like the Heavenly child." (Zipes: 61)

In this case, there is rhyme - at the expense of compactness - and in terms of content, the rendition is by far the one closest to the original and has a religious strand of nearly the same calibre as the original. The 'only' problem is therefore whether this sits well with a modern American audience. Surely a cultural and chronological constraint of no minor magnitude.

In terms of fluency for reading aloud, the 1853 (anonymous) and Crane's (1882) translations still fare best. Hunt (1884) trails far behind Zipes (1987).

\section{Names, wordplay, cultures, and rhyme}

The British author Roald Dahl wrote many children's stories, among them Fantastic Mr. Fox (1970). In the brief opening chapter, we are introduced to three nasty farmers with revolting eating habits. In the original they are "Farmer Boggis, Farmer Bunce and Farmer Bean." Boggis is a chicken farmer who is enormously fat because he eats "three boiled chickens smothered with dumplings every day for breakfast, lunch and supper." Bunce is a duck-and-goose farmer, a pot-bellied dwarf who eats doughnuts and goose livers. "He mashed the livers into a disgusting paste and then stuffed the paste into the doughnuts." Bean is a turkey-and-apple farmer. He is thin. He never eats anything, but he drinks "gallons of strong cider which he made from the apples in his orchard." So the children chant:

"Boggis and Bunce and Bean

One fat, one short, one lean. 
These horrible crooks

So different in looks

Were nonetheless equally mean."

It is noted that this is quite a problematic text. It is, first and foremost, humorous. But at the linguistic layer there is a problem in that their names alliterate.

The translation of 1975: 'Mageløse hr. Mikkel.'

The first individual approach

The Danish translation came out in 1975 with Donald Chaffin's illustrations for the English original. The two black-and-white pictures showed the three farmers and their dishes in a sketchy way. Nevertheless, they constituted paratextual constraints on the translator. The translator, Mr Jens Louis Petersen, was an established translator and author of performative texts (librettos for operas and songs for cabarets) but relatively old (about 60 years of age). Overall, his translation is highly readable. He terms the three farmers "Bred" (=Fat), "Bidsk" (=Gruff), and "Bønne" (=Bean). The language is educated fairly old-fashioned Danish and contains long words that must have been dropping out of use at the time of publication (e.g., "nederdrægtigste," "lavstammet," "swimmingpool," "fedtegreve"). The target group must therefore have been fairly narrow: children in educated families whose grandparents would find the story fun to read - a feature certainly emphasised in the plays on words and exaggerations. The final chant has a rhyme scheme corresponding to that of the English original (aabba). To this Mr. Petersen adds alliteration: "Fæle forbryd're ... hver én lumpen og led."

The main problem in any Danish translation is the nature of the disgusting food. Three chickens in cream sauce for Boggis is a lot but not necessarily revolting. Bunce's food is incomprehensible to virtually all Danish children in 1975: "fedtegrever" and "gåseleverpostej" were ingredients in (fat) food in the agricultural households in the first part of the 20th century but were rare in the urbanised Denmark of the 1970s. On the other hand, the rendition of 'cider' as the somewhat more alcoholic "apple wine" (which was sold extensively at the time) might ring a bell with some children. The cider container in the drawing was changed to 'vin' so as to correspond with the text, so here the constraint was neutralised. ${ }^{14}$

Overall, the intentionality is the same, namely to present some unsavoury characters. The linguistic layer is emphatic in Danish: unlike the English original, it includes alliteration and extremes (superlative forms). The three names all have a meaning, which was not the case in the original. In this case, a Danish translator is faced with a culture-bound problem: generally speaking, Danes are accustomed to translated books (at the time they would have amounted to about one third of all books published and now the percentage is much higher). Therefore they would immediately suspect translator incompetence if the characters' names were not meaningful (collating with the original not being a real option since it would take several weeks to procure it). The translator is therefore forced to come up with meaningful names. ${ }^{15}$ Content-wise, and in terms of culture, the translator is not successful in making the eating habits seem revolting, in the first case because there is nothing bad in itself about eating chicken, and in the second because the food would seem outdated to the audience. 


\section{Graduate students: the consensus approach}

The English text happened to come into my hands before I - in my research for this article - found out that it was translated into Danish. I therefore used it in graduate translation classes with Chaffin's black-and-white illustrations. The translations were meant to give students an insight into problems in translating literature for children, and they have always been subjected to discussion in class, where we reached a kind of consensus on problems and good solutions.

Most students had, on their own, realised that reading aloud the translation was important.

There was complete agreement that the more sense the names made, the better.Among the combinations of the three names that have met with approval were "Bolle" (= bun), "Bølle” (= hooligan), "Bønne"; "Hr. Tyk," "Hr. Tynd," and "Hr. Tumling" (the only suggestion which made for a difference at the structural layer because then the final stanza would work in terms of rhythm albeit not rhyme), and even "Hr Bandit" (= scoundrel), "Hr Ballade" (= row), and "Hr Bønne."

All translations of the names were consistent with the chant given at the end in the Danish renditions. The length of this chant varied from four to six lines, but the overall intentionality was the same: a summary of how nasty the farmers are.

The food was the main stumbling block. The two best solutions for Boggis' meals were to use incongruous ingredients, e.g., chickens stuffed with meat balls, or chicken with brown sauce (a Danish specialty favoured by elderly people in combination with pork or minced beef); several raised the question as to whether travelled Danes would know "dumplings," but the majority agreed that children would not. Bunce's meals were even more problematic since "doughnuts" are virtually unknown in the target group. The defining characteristic of the cake suggested in a bilingual dictionary, a "vaniliekrans," is that the hole in this type of cake goes right through it. A non-committal 'cake with a hole in it' was acceptable, but the two types of pastry made in Denmark which may have some ingredients inside, "fastelavnsboller" (popular for a couple of days a year) or, even more appropriate, "æblekager" (which are sweetish and should have a piece of apple in the middle), were incongruous enough to make it. Bean's food is problematic, since 'cider' is not popular (but still known) in Denmark. The most popular choice - apple wine - is, as hinted, fairly strong. So, stressing the disgusting aspect, "sticky apple juice" seemed the best solution.

\section{The 1998 translation: the second individual approach}

The book was reissued with new illustrations in 1996, no less than five for the first chapter alone: one for the three characters, one for their specific eating habits, and a final one with children chanting the song. This was a co-print produced in Singapore, and the new Danish publisher used another translator, Glenn Ringtved who thus represents the individual, professional translator.

Overall, the language is idiomatic, fluent and easy to read.

The names begin with an 'S' so the three men are now "Strid" (= tough), "Strut" (= strut (the imperative form)), and "Stage" (= stalk), thus illustrating what I said above, namely that a translator in Denmark will have to bend a text to be more consistent or be accused of incompetence. The names are consistent in the poem and the six-line poem brings across the intentionality. 
Boggis' meal is just chicken, which again implies only overeating. Bunce is now pouring his goose-liver paste on Danish pastry but unfortunately on an elongated type ("wienerbrød") whereas the picture shows some rings. But after drinking 'several litres of strong apple wine' (11-12\% alcohol), Bean can hardly be, as Roald Dahl originally put it "the cleverest of them all" for more than a couple of minutes per day.

The linguistic layer is once again stronger, but the content layer is another.

Yet the intentionality has, again, been preserved.

\section{Conclusion}

Practising translators will be happy to know that few readers-aloud and their audiences are as critical as translation critics.

It is difficult, indeed tricky, to translate children's fiction. It is, furthermore, an art which has largely been taken over by women in Denmark as of the middle of the 20th century. This does not tally with, for instance, the English scene, where women translators dominated children's literature nearly one hundred years before. So there are great variations in the national scenes in this respect (Dollerup 1999: 320).

The above study does bring out the fact that the same source texts may be targeted towards different audiences both of which will, to the undiscriminating eye, appear to be children. They do, however, divide into two different categories: one is adapted for reading aloud and the other is not. The translations of Grimm into English by the anonymous translators (1853) and by Crane (1882) are fluent and still in print. Hunt (1884) has been philologically 'faithful' and therefore appears to have appealed more to silent readers or to people who just wanted to have a Grimm collection on the shelves to show their knowledge of European culture. In any event it does not make for good reading aloud. This is even more obvious with the Danish Grimm translation of 1995. There is a clash between translations clearly made for reading aloud to children and more philologically oriented translations that adhere to traditional standards of translational fidelity. Translators, let alone publishers, do not seem to be aware of this in all countries. As far as the Grimm (and Andersen) stories are concerned, it seems as though philological translations are an endangered species. Hovering over these are the shadows of 'copyright,' of 'droit morale,' and the question of whether the Andersen and Grimm tales have served their turn in the development of Western civilisation by emphasising the importance of decent behaviour and sensitivity. In any event, it seems that their fairytales are disappearing from view in Western culture. I find it interesting to note that there are few reports about fairytales finding favour with children today. This, however, is a question of greater societal changes that are beyond the scope of the textual studies that I have focused on in this article.

What is interesting in an international perspective is the fact that co-prints are making marked advances. Previously, they seemed to be mostly confined to one major language and a host of minor ones: For a co-print to merit publication and earn a profit in Denmark, there must be at least 500 copies sold. ${ }^{16}$ But if we are to judge from the appearance of the American Where is My Teddy in France, co-prints are also making inroads in major countries in the market for picture and children's books.

In so far as books are translated and meant for interaction between children, their parents or grandparents, fluency in the target language and fairly precise lin- 
guistic targeting in terms of age are of prime importance. For children who cannot yet read, the translator has to prepare stories for oral rendition. The translator can actually only do this by personally reading the stories aloud. This corresponds to the fairly few reports I have from translators of stories that are meant to be read aloud, but there is still little indication that Translation Studies scholars are aware of this.

In this discussion, we have compared a number of originals with realisations in other languages. This has been done at the structural, linguistic, content, and intentional layers to which we have added paratextual and chronological perspectives. The material in no way allows for statistical analysis, and it is, furthermore, confined to translations that most readers will find 'adequate' and take seriously as linguistic reflections of the original. We may therefore cautiously and intuitively refer to 'renditions' which are 'freer.' Let it be stated clearly and loudly that these translations represent deviations at all levels and concerning all aspects that I have singled out for analysis. Surprisingly enough, the structural layer seems to be rendered most 'faithfully' - but this goes only for respectable translations. There is much freedom in translation at the linguistic layer. The content layer shows curious and sometimes contextually inexplicable variation. And the intentional layer may change, notably when the target culture is devoid of the objectives of rigid intentionalies (e.g., political satire, religion).

In other words: the translation of children's books for reading aloud makes a mockery of much elevated thinking in Translation Studies. It is not only because 'children's literature for reading aloud' is a special field (or developing into one) in many Western countries but also because much advanced thinking in Translation Studies focuses on 'privileged texts' that underpin rather than undermine the authors' tenets. It is thought-provoking that, beyond the pale of the 'privileged texts for translation,' any major school in Translation Studies will have problems with the features discussed in this article.

On the other hand, it is certainly true that children's literature will contain more deviations than most other types of translation. This is because reading aloud must be a pleasure, it must be fun. This is a prerequisite for the establishment of a 'narrative contract' between children and their elder brothers and sisters, parents, or grandparents in order to strengthen familial intimacy and loyalty. 'Narrative contracts' are part of a tradition cherished by humans ever since the first story was told. And translation makes a substantial contribution to the development of this tradition.

\section{NOTES}

1. The best textual editions of the Grimm tales have been published by Heinz Rölleke from 1975 onwards. Unfortunately his reprint of the 1819 edition leaves out the forty-page introduction on the relationship between Norse mythology and the German tales the brothers had collected.

2. For background information about the following summary, readers are referred to Dollerup (1999) or Rölleke (1985).

3. I have proved that copies were available to Professor Nyerup, Adam Oehlenschläger, Chamberlain Lindencrone, and Matthias Thiele (Dollerup 1999: 149). Diligent searches in booksellers' catalogues and private Copenhagen libraries will undoubtedly unearth more copies.

4. Jacob Grimm was not mentioned. During the Napoleonic wars, Denmark was the only country to side with Napoleon, and Professor Rasmus Nyerup, who was a true Danish patriot (and had unsuccessfully tried to spy on Sweden), was clearly upset with the ease with which Jacob Grimm, who had been in the employ of Napoleon's brother, King Jérôme of Westphalia, switched sides to serve the German Kurfürst Wilhelm, who had his lands restored at the Congress of Vienna.

5. The importance of translation for the international promotion of Grimm and Andersen tales is detailed in Dollerup 1999: 279-285. 
6. There were books prior to the Grimm Tales that were for children. From the literature available to me, it is not clear to what extent these early books were meant for reading aloud.

7. The two pertinent questions in the informal questionnaire ran: "What types of literature are read aloud to children? (Narratives/ Non-fiction/ Poetry)," and "Focusing on narratives, what percentage would you, overall, believe was spent on: /international fairytales (Grimm, Andersen, Aesop)/ Old national stories/International co-prints (check the colophons!)/ Children's fiction written by national writers/"

8. It is often overlooked that 'success' on the home market is a prerequisite for a book's selection (via national or international promotion) for translation. This mechanism applies to all translated books.

9. Sutton actually cites the preface of this edition and its reference to mothers (164), and he repeatedly refers to British mothers $(169,180)$ but says that they would be looking for "suitable reading material for their children" (180), not for reading aloud to their children.

Just for the record: I noted in passing at the beginning of the article that all long-lived German translations of Andersen seem to derive from less than five 'real translations.' This also seems to apply to the English translations of Grimm. In fact, this is also, to some extent, true of the Danish scene as discussed in Dollerup 1999. The difference could be due to the depth of the check. Mine of Andersen in Germany was done electronically. Sutton's study is based on the holdings of the Grimm-Museum in Kassel, the British Library, and a few others. Tales and Translation is based on an exhaustive analysis of the Danish copyright library holdings ascribed to Grimm (but not in journals, magazines, etc.).

10. Sutton mentions numerous examples of purgation in the English translations of the Grimm Tales (1995), but unfortunately the background information and the assessment of the overall quality of the translation he offers is too sketchy to make out who undertook the purgation and whether it was due to poor knowledge of German or not. I do not know of any study of differences between originals and translations of classical literature that takes into account such elementary problems as 'knowledge of the source language.' However, I vividly remember my surprise when I read Gulliver's Travels (Book 1) in English and found out that Gulliver puts out the fire in the Queen's quarters by urinating on the flames. In the respectable and highly esteemed Danish translation which I had read in my childhood, Gulliver put out the fire by pouring small buckets of wine on the flames. The purgation may not have been in the translation, but the publisher and the translator may have received a bowdlerised British edition.

11. Over the course of a year, I read out the Complete Collection of the Tales to my children then aged c 5 and 7. Being reasonably good at reading out 'prima vista,' I did not check the stories beforehand. The ending of some stories was followed by stunned silence.

12. After the first edition had come out in Germany (1812-15), Wilhelm Grimm took over as the only editor of the Tales. There is no indication that Jacob Grimm disagreed with his 'editorial improvements.' All told, Wilhelm Grimm was in charge of six 'Large Editions' and ten 'Small Editions,' the last one appearing in 1857.

13. I wish to thank Jill Archer for having called my attention to this book.

14. Publishers are somewhat unhappy about changing texts in drawings. Redrawing frames and changing texts can be done in black-and-white originals, but careful inspection always reveals telltale traces of tampering (see also Dollerup and Orel-Kos 2001: 106).

15. Retaining the English names is a poor solution, because they sound meaningful, and it requires a check in dictionaries to justify the translator's decision. This can hardly be expected of people who read books aloud to children.

16. In Denmark there is a tradition for authors and actors to read aloud for adult audiences. In 2001, the company 'Gate 2 history' issued CD-ROMs with readings of Hans Christian Andersen's fairytales. The readings were in Danish, Swedish, German, English, and French. The readers included Clara Pontopiddan and Osvald Helmuth, Ingrid Bergman and Bibi Anderson, Gisela May and Günter Grass, Sir Laurence Olivier and Sir John Gielgud, Michel Simon and Jeanne Moreau, in their respective languages. The review I saw (Weekendavisen 16 November 2001. 2: 5) did not mention the translators but was enthusiastic about the readings. In other words: it is not only children who enjoy being read to.

\section{REFERENCES}

Note: references to the children's books, tale collections, and translations in the text are sufficient for identification. Accordingly, these are not given in the below list.

Anz, H., B. Kristiansen and F. Lundgreen-Nielsen (2000): Views. Copenhagen: University of Copenhagen. 
Dollerup, C. (1999): Tales and Translation: The Grimm Tales from Pan-Germanic narratives to shared international fairytales. Amsterdam \& Philadelphia: John Benjamins.

Dollerup, C. and S. Orel-Kos (2001): Co-prints and translation. Perspectives: Studies in Translatology 9. 87-108. An expanded version of: Co-printing: Translation without Boundaries. In: Hebenstreit, Gernot (Hrsg). 2001. Grenzen erfahren - sichtbar machen - überschreiten: Festschrift für Erich Prun? zum 60. Geburtstag. Frankfurt \& Wien: Peter Lang. 285-300.

Houlind, M. (2001): Translation and adaptation. Perspectives: Studies in Translatology 9. 127-138. Jones, G. (1993): Hvad har de dog gjort ved Andersen? En historie til skræk og advarsel. In: Pedersen, Viggo Hjørnager (ed.). Om at oversette H.C. Andersen. København: Centre for Translation Studies.

Oittinen, R. (1993): I Am Me - I Am Other: On the Dialogics of Translating for Children. Tampere: University of Tampere.

Oittinen, R. (2000): Translating for Children. New York: Garland.

Oittinen, R. (2001): On translating picture books. Perspectives: Studies in Translatology 9. 109-125. Rölleke, H. (1985): Die Märchen der Brüder Grimm: eine Einführung. Munich \& Zurich: Artemis. (Heinz Rölleke has published textual editions of the Grimm Tales since 1975. This is a good introduction)

Rölleke, H. (1987): Brüder Grimm. Orig. 1857. Kinder- und Hausmärchen. Vol. 1-3. Stuttgart: Philipp Reclam.

SeAgo, K. (2001): Review of Dollerup 1999. Marvels \& Tales: Journal of Fairy-Tale Studies. 119-123. Sutton, M. (1996): The Sin-Complex: a critical study of English versions of the Grimms' Kinderund Hausmärchen in the nineteenth century. Kassel: Brüder Grimm-Gesellschaft Kassel.

Zipes, J. (1992) (orig. 1987): The Complete Fairytales of the Brothers Grimm. New York \& Toronto, etc.: Bantam Books.

\section{APPENDIX}

By country in alphabetical order

\begin{tabular}{|c|c|c|c|c|c|c|c|c|}
\hline Country & $\begin{array}{l}\text { Reading } \\
\text { aloud is }\end{array}$ & $\begin{array}{l}\text { readers will } \\
\text { typically be }\end{array}$ & $\begin{array}{l}\text { audience } \\
\text { age }\end{array}$ & $\begin{array}{l}\text { not beyond } \\
\text { (age) }\end{array}$ & $\begin{array}{l}\text { type of } \\
\text { material }\end{array}$ & genres & $\begin{array}{c}\text { special } \\
\text { comment }\end{array}$ & Source \\
\hline Belgium & Common & Mothers & 0 to $\mathrm{c} 7$ & $\begin{array}{l}\text { When they } \\
\text { read } \\
\text { themselves }\end{array}$ & & & $\begin{array}{l}\text { Television } \\
\text { is chang- } \\
\text { ing this. }\end{array}$ & $\begin{array}{l}\text { Christine } \\
\text { Pagnoulle }\end{array}$ \\
\hline China & Common & $\begin{array}{l}\text { Mothers, } \\
\text { fathers, } \\
\text { grandpar- } \\
\text { ents }\end{array}$ & $\begin{array}{l}0 \text { to pre- } \\
\text { school }\end{array}$ & 5 to 7 & $\begin{array}{l}\text { Narratives, } \\
\text { Poetry }\end{array}$ & $\begin{array}{l}\text { Fairytales, } \\
\text { National } \\
\text { stories }\end{array}$ & & $\begin{array}{l}\text { Shen } \\
\text { Rongjie } \\
\text { Li Yunxing }\end{array}$ \\
\hline Denmark & Common & $\begin{array}{l}\text { Mothers, } \\
\text { fathers, } \\
\text { babysitters }\end{array}$ & 0 to 8 & 8 to 10 & Narratives & $\begin{array}{l}\text { Fairytales, } \\
\text { National } \\
\text { authors, } \\
\text { Co-prints }\end{array}$ & $\begin{array}{l}\text { The } \\
\text { pattern } \\
\text { seems to } \\
\text { be chang- } \\
\text { ing. }\end{array}$ & $\begin{array}{l}\text { Class of } \\
\text { graduate } \\
\text { students }\end{array}$ \\
\hline Finland & Common & $\begin{array}{l}\text { Mothers, } \\
\text { fathers, } \\
\text { grandpar- } \\
\text { ents, older } \\
\text { siblings, } \\
\text { babysitters }\end{array}$ & $\begin{array}{l}1 \text { to end } \\
\text { of third } \\
\text { year in } \\
\text { school }\end{array}$ & $\begin{array}{l}10=\text { when } \\
\text { children } \\
\text { stop } \\
\text { listening }\end{array}$ & $\begin{array}{l}\text { Narratives, } \\
\text { Poetry }\end{array}$ & $\begin{array}{l}\text { Andersen } \\
+ \text { Grimm } \\
(10 \%), \\
\text { National } \\
\text { stories } \\
(10 \%), \\
\text { Co-prints } \\
(10 \%), \\
\text { National } \\
\text { children's } \\
\text { authors } \\
(70 \%)\end{array}$ & $\begin{array}{l}\text { The } \\
\text { experience } \\
\text { with } \\
\text { reading } \\
\text { aloud is } \\
\text { changing, } \\
\text { both in } \\
\text { terms of } \\
\text { circum- } \\
\text { stances and } \\
\text { reading } \\
\text { material. }\end{array}$ & $\begin{array}{l}\text { Ritva } \\
\text { Leppi- } \\
\text { halme }\end{array}$ \\
\hline
\end{tabular}




\begin{tabular}{|c|c|c|c|c|c|c|c|c|}
\hline Country & $\begin{array}{l}\text { Reading } \\
\text { aloud is }\end{array}$ & $\begin{array}{l}\text { readers will } \\
\text { typically be }\end{array}$ & $\begin{array}{l}\text { audience } \\
\text { age }\end{array}$ & $\begin{array}{c}\text { not beyond } \\
\text { (age) }\end{array}$ & $\begin{array}{l}\text { type of } \\
\text { material }\end{array}$ & genres & $\begin{array}{c}\text { special } \\
\text { comment }\end{array}$ & Source \\
\hline Hungary & Common & $\begin{array}{l}\text { Mothers, } \\
\text { fathers, } \\
\text { grandpar- } \\
\text { ents }\end{array}$ & $\begin{array}{l}1 \text { to pre- } \\
\text { school }\end{array}$ & 6 & $\begin{array}{l}\text { Narratives, } \\
\text { Poetry }\end{array}$ & $\begin{array}{l}\text { Fairytales, } \\
\text { Old na- } \\
\text { tional } \\
\text { stories, } \\
\text { National } \\
\text { children's } \\
\text { fiction }\end{array}$ & & $\begin{array}{l}\text { Albert } \\
\text { Sándor }\end{array}$ \\
\hline Poland & $\begin{array}{l}\text { Common } \\
\text { Rare }\end{array}$ & $\begin{array}{l}\text { Mothers, } \\
\text { fathers, } \\
\text { grandpar- } \\
\text { ents }\end{array}$ & $\begin{array}{l}1 \text { to after } \\
\text { three years } \\
\text { in school }\end{array}$ & $\begin{array}{l}9 \text { to } 11-12 \\
=\text { when } \\
\text { they start } \\
\text { reading } \\
\text { themselves }\end{array}$ & $\begin{array}{l}\text { Narratives, } \\
\text { Poetry }\end{array}$ & \begin{tabular}{|l|} 
Fairytales \\
(35\%-- \\
$50 \%)$, \\
National \\
stories \\
$(15 \%-$ \\
$25 \%)$, \\
National \\
children's \\
fiction \\
$(50 \%-25 \%)$
\end{tabular} & $\begin{array}{l}\text { There are } \\
\text { changes } \\
\text { in family } \\
\text { patterns. } \\
\text { Previ- } \\
\text { ously } \\
\text { mothers } \\
\text { would do } \\
\text { most } \\
\text { reading. }\end{array}$ & $\begin{array}{l}\text { Elzbieta } \\
\text { Wojcik- } \\
\text { Leese, } \\
\text { Elżbieta } \\
\text { Taba- } \\
\text { kowska, } \\
\text { Jerzy } \\
\text { Şwiatek }\end{array}$ \\
\hline Romania & Common & $\begin{array}{l}\text { Mothers, } \\
\text { fathers, } \\
\text { grandpar- } \\
\text { ents, older } \\
\text { siblings, } \\
\text { nannies }\end{array}$ & $\begin{array}{l}3 \text { to pre- } \\
\text { school }\end{array}$ & $\begin{array}{l}7=\text { when } \\
\text { they start } \\
\text { school }\end{array}$ & $\begin{array}{l}\text { Narratives, } \\
\text { Poetry }\end{array}$ & $\begin{array}{l}\text { Fairytales } \\
(40 \%), \\
\text { National } \\
\text { stories } \\
(40 \%), \\
\text { National } \\
\text { stories } \\
(20 \%)\end{array}$ & & $\begin{array}{l}\text { Rodica } \\
\text { Dimitriu }\end{array}$ \\
\hline Russia & Common & $\begin{array}{l}\text { Mothers, } \\
\text { fathers, } \\
\text { grandpar- } \\
\text { ents }\end{array}$ & $\begin{array}{l}1 \text { to first } \\
\text { three years } \\
\text { in school }\end{array}$ & 8 to 10 & $\begin{array}{l}\text { Narratives, } \\
\text { Poetry }\end{array}$ & $\begin{array}{l}\text { Fairytales } \\
(20 \%), \\
\text { Old na- } \\
\text { tional } \\
\text { stories } \\
(20 \%), \\
\text { National } \\
\text { children's } \\
\text { fiction } \\
(60 \%)\end{array}$ & $\begin{array}{l}\text { The } \\
\text { observa- } \\
\text { tions may } \\
\text { not apply } \\
\text { to all } \\
\text { Russians. }\end{array}$ & $\begin{array}{l}\text { Alla } \\
\text { Podgor- } \\
\text { naya }\end{array}$ \\
\hline Slovenia & Common & $\begin{array}{l}\text { Mothers, } \\
\text { fathers, } \\
\text { grandpar- } \\
\text { ents, } \\
\text { siblings, } \\
\text { family } \\
\text { friends }\end{array}$ & $\begin{array}{l}1 \text { to first } \\
\text { three years } \\
\text { in school }\end{array}$ & c 9 & $\begin{array}{l}\text { Narratives, } \\
\text { Poetry }\end{array}$ & 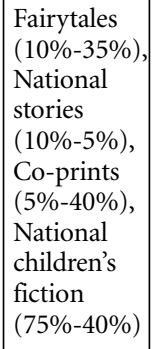 & & $\begin{array}{l}\text { Marija } \\
\text { Zlatnar } \\
\text { Moe, } \\
\text { Silvana } \\
\text { Orel-Kos }\end{array}$ \\
\hline Spain & Common & $\begin{array}{l}\text { Mothers, } \\
\text { fathers }\end{array}$ & $\begin{array}{l}1 \text { to pre- } \\
\text { school }\end{array}$ & 6 & Narratives & $\begin{array}{l}\text { National } \\
\text { stories }\end{array}$ & & $\begin{array}{l}\text { Federico } \\
\text { Chaume } \\
\text { Varela }\end{array}$ \\
\hline Turkey & Common & $\begin{array}{l}\text { Mothers, } \\
\text { fathers, } \\
\text { grandpar- } \\
\text { ents } \\
1 \text { to first }\end{array}$ & $\begin{array}{l}\text { three years } \\
\text { in school } \\
\text { Two years }\end{array}$ & $\begin{array}{l}\text { after } \\
\text { entering } \\
\text { school } \\
\text { Narratives, }\end{array}$ & $\begin{array}{l}\text { Poetry } \\
\text { Fairytales }\end{array}$ & $\begin{array}{l}(80 \%), \\
\text { Old na- } \\
\text { tional } \\
\text { stories } \\
(5 \%), \\
\text { National } \\
\text { children's } \\
\text { fiction } \\
(10 \%)\end{array}$ & & $\begin{array}{l}\text { Sebnem } \\
\text { Susam } \\
\text { Sarajeva }\end{array}$ \\
\hline
\end{tabular}

